\title{
Differences in the adsorption of enzymes onto lignins from diverse types of lignocellulosic biomass and the underlying mechanism
}

\author{
Fenfen Guo, Wenjing Shi, Wan Sun, Xuezhi Li, Feifei Wang, Jian Zhao* and Yinbo Qu
}

\begin{abstract}
Background: Non-productive cellulase adsorption onto lignin has always been deemed to negatively affect the enzymatic hydrolysis of lignocellulosic feedstocks. Therefore, understanding enzyme-lignin interactions is essential for the development of enzyme mixtures, the processes of lignocellulose hydrolysis, and the genetic modification of lignocellulosic biomass and enzymes. In this work, we examined the properties of six lignins from diverse types of lignocellulosic biomass (aspen, pine, corn stover, kenaf, and two Arabidopsis lines, wild-type and SALK mutant of fah1) to determine the mechanism of differences in their adsorption of enzymes.

Results: We found that lignin sources affected enzyme adsorption using structural features, such as functional groups and lignin composition. Guaiacyl (G) lignin had a higher adsorption capacity on enzymes than syringyl (S) lignin. The low S/G ratio and high uniform lignin fragment size had good correlations with high adsorption capacity. A higher content of phenolic hydroxyl groups and a lower content of carboxylic acid groups resulted in stronger adsorption affinity for corn stover lignin $(\mathrm{CL})$ than for kenaf lignin $(\mathrm{KL})$ and aspen lignin (AL). The lower amount of aliphatic hydroxyls that reduced hydrophobic interactions could explain the higher adsorption capacity of pine lignin (PL) than CL. Enzyme activity assays, as well as the hydrolysis of Avicel, phosphoric acid-swollen cellulose (PASC), and holocellulose, were performed to study the behaviors of mono-component enzymes that resulted in adsorption. We found that cellobiohydrolase $(\mathrm{CBH})$ and xylanase were adsorbed the most by all lignins, endoglucanase ( $E G$ ) showed less inhibition, and $\beta$-glucosidase $(B G)$ was the least affected by lignins, indicating the important role of carbohydrate-binding module (CBM) in protein adsorption.

Conclusion: Lignin sources affect enzyme adsorption using structural features and lignin composition, such as S/G ratio, carboxylic acid, aliphatic hydroxyl, and phenolic hydroxyl. For mono-component enzymes, the adsorption capacity decreased in the order $\mathrm{CBH}$, xylanase > EG > BG. These investigations revealed the difference in lignin properties between diverse biomass and adsorption capacity of enzymes to lignins, and the possible underlying mechanism. The results can also serve as a reference for the genetic modification of lignocellulosic biomass and enzymes.
\end{abstract}

Keywords: Enzyme adsorption, Diverse types of biomass, Lignin property, S/G ratio

\section{Background}

The conversion of lignocellulosic materials into bioethanol has drawn worldwide attention because of concerns about the depletion of fossil fuels. Two major constituents of lignocellulosic biomass, cellulose and hemicellulose, can be converted to fermentable sugars. However, another main component, lignin, has been always deemed to have a negative impact on the saccharification of lignocellulosic

\footnotetext{
* Correspondence: zhaojian@sdu.edu.cn

State Key Laboratory of Microbial Technology, Shandong University, Ji-nan City, Shandong Province 250100, China
}

feedstocks by physically barring and unproductively adsorbing hydrolytic enzymes [1-3].

Lignin is an aromatic cell wall polymer in vascular plants. It encrusts and glues the network of cell wall carbohydrates together, stiffening the cell wall structure. Its biosynthesis occurs through the radical coupling of the lignin precursors, coniferyl, sinapyl, and $p$-coumaryl alcohol, giving rise to a random sequence of guaiacyl (G), syringyl $(\mathrm{S})$, and hydroxyphenyl $(\mathrm{H})$ subunits in the polymer, respectively. The sequence varies from plant to plant, and the ratio of $G, S$, and $H$ units significantly differ in 
softwood, hardwood, and grass species. However, three main types are recognized: softwood lignin is mainly composed of $G$ units (G-type), whereas both $G$ and $S$ units are abundant in hardwood (GS-type). In addition to G and S units, $\mathrm{H}$ units are also present in grasses and compression wood lignin (GSH-type). However, to date, no study has been conducted about the adsorption of enzymes onto lignins from these diverse types of biomass. Whether the difference in lignin composition affects adsorption capacity is also unclear. Moreover, the genetically engineered biomass with modified S/G ratio in lignin, which serves as a more promising sugar source for ethanol production, is being actively studied $[4,5]$. Thus, further understanding between lignin composition and enzyme adsorption could guide the genetic modification of biomass.

The adsorption of enzymes onto isolated lignins has been widely studied, and most of the studies involve different enzymes or lignins extracted from pretreated materials $[1,2,6,7]$. In a previous study, cellulases and xylanases have been found to be significantly affected by lignin, with $\beta$-glucosidase (BG) being the least affected [1]. Carbohydrate-binding module (CBM) has been identified to play an important role in protein adsorption [2]. The adsorption capacity has been found to differ among various lignins from pretreated materials [6]. Using the good correlation between the hydrolysis yields of the pretreated lignocellulose and Avicel containing the isolated lignin, Nakagame et al. [8] reported that native differences in lignin may be the reason for the differences in their inhibitory properties. However, the mechanism on how it affects the inhibitory hydrolysis was not explained. Pan [9] also found that the hydrolysis inhibition was dependent on lignin sources and the structural features of lignin, like how functional groups were important for enzyme-binding or the enzyme-interfering capacity of lignin. However, comparison studies on the adsorption capacities of native lignins from diverse types of biomass that consider their physicochemical properties have not been conducted. Therefore, it is of interest to study them in terms of total protein adsorption and mono-component enzyme adsorption to help elucidate the fundamentals behind protein adsorption. Proper understanding of the lignin structures that promote enzyme adsorption could help provide a reference for the genetic modification of lignocellulosic biomass.

It is well known that hydrophobic interactions have been identified to be a major driving force for protein adsorption onto lignin $[1,6]$. For functional groups, which affect lignin-enzyme interactions, a low carboxylic acid group content and a higher phenolic hydroxyl content in lignins could result in the increased protein adsorption capacity [2], and the data by Berlin et al. [1] also indicate that the polydispersity index (PDI) is inversely related to the interaction of the polymer with the protein.
The present study focuses on the adsorption of the enzyme from Penicillium oxalicum JU-A10-T onto lignin preparations from diverse types of biomass (softwood, hardwood, and herbaceous plants) and two Arabidopsis lines (wild-type and SALK mutant of fah1). The differences in the properties of lignins, such as chemical functionalities, molecular weight, PDI, and composition, were also determined to investigate their potential connections to enzyme adsorption affinity.

\section{Results and discussion}

\section{Adsorption of cellulase onto lignins from different types of lignocellulosics}

To compare the adsorption of extracellular proteins in crude enzymes from the liquor fermentation of $P$. oxalicum to that in lignins from diverse types of biomass, $5.4 \mathrm{mg}$ protein/g lignin mixed systems were made, because evident change and difference in the protein band could be clearly observed in the reaction system, according to a previous study (data not shown). The changes in protein content resulting from the adsorption by lignins are shown in Figure 1, and the visible differences in protein band change could also be observed in SDSPAGE (data not shown). Obviously, there were significant differences in the adsorption capability of cellulase onto lignins among the various lignocellulosic materials. Corn stover lignin (CL) and pine lignin (PL) had the highest adsorption affinity on the enzyme, and aspen lignin (AL) had stronger adsorption capacity than kenaf lignin (KL). The adsorption capacity decreased in the order $\mathrm{PL}>\mathrm{CL}>\mathrm{AL}>\mathrm{KL}$. For the two Arabidopsis lines, Arabidopsis SALK mutant 063792 lignin (ASL) adsorbed significantly more protein than Arabidopsis Col-0 lignin (ACL).

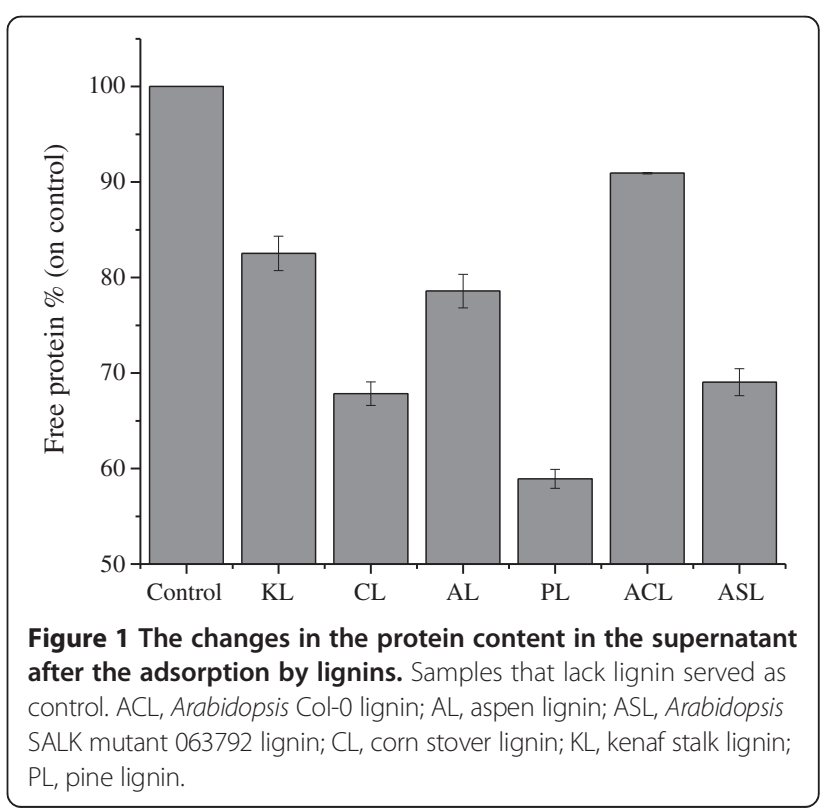


Inhibitory effects of lignins on mono-component enzymes Protein quantification provides an overview of the enzyme adsorption capacities of the lignin preparations. To gain insight about the adsorption of prominent enzymes in the protein preparations studied, activity assays for cellobiohydrolase $(\mathrm{CBH})$, endoglucanase (EG), BG (cellulase), and xylanase (hemicellulase) were performed (Figure 2A). Similarly, the behavior of the mono-component enzyme that resulted in adsorption could also be observed in the hydrolysis of Avicel and phosphoric acid-swollen cellulose (PASC), representing the change of $\mathrm{CBH}$ and $\mathrm{EG}$, respectively, and holocellulose, representing the change of xylanase and total cellulase (Figure 2B). These show that CL and PL had the most significant decrease in enzyme activities, and $\mathrm{CBH}$ and xylanase were adsorbed the most by all lignins. EG was less inhibited, which may be attributed to the difference in protein structure, like hydrophobic sites. BG, which had no CBM, was the enzyme least affected by the lignins (Figure 2). According to the results of the hydrolysis of holocellulose, total cellulase was found to have a stronger inhibition effect on lignins than xylanase. Berlin et
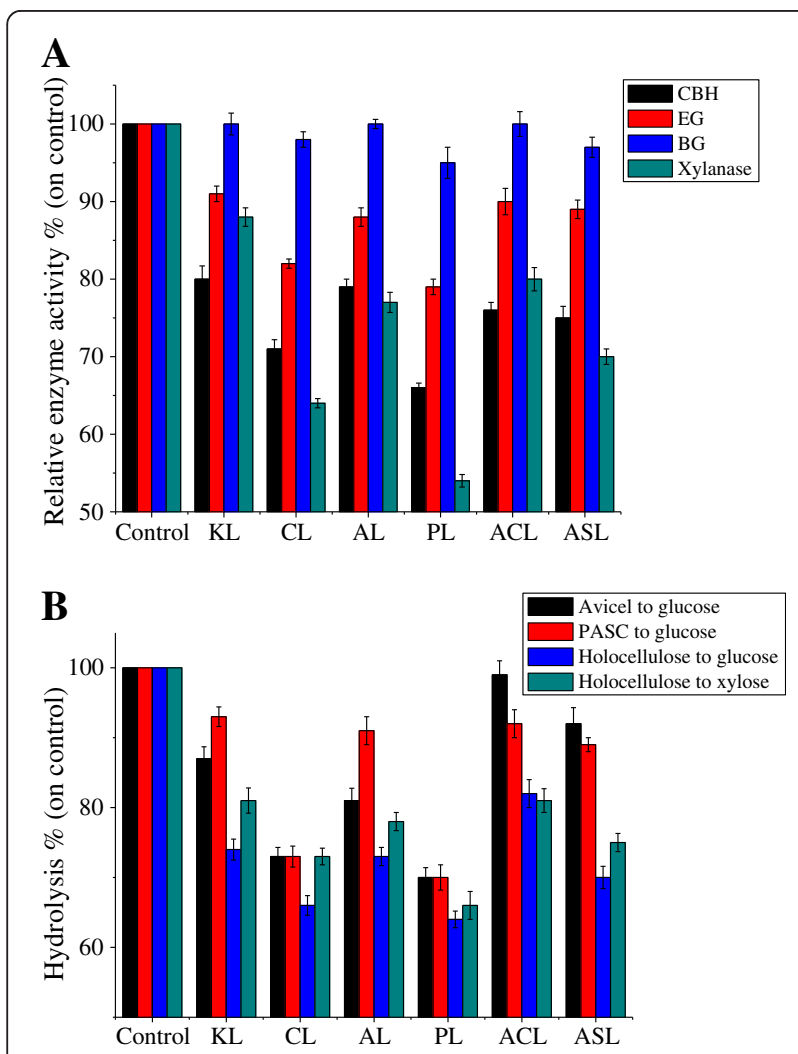

Figure 2 (A) The changes of enzyme activities and (B) the inhibition effect of lignins on the enzymatic hydrolysis of various celluloses. Samples without lignin served as control. $A C L$, Arabidopsis Col-0 lignin; AL, aspen lignin; ASL, Arabidopsis SALK mutant 063792 lignin; BG, $\beta$-glucosidase; $\mathrm{CBH}$, cellobiohydrolase; $\mathrm{CL}$, corn stover lignin; EG, endoglucanase; KL, kenaf lignin; PASC, phosphoric acid-swollen cellulose; PL, pine lignin. al. [1] also reported that cellulases and xylanases are significantly affected by lignin, and BG was the enzyme that was least affected. In cellulase, $\mathrm{CBH}$ is found to have a higher affinity to lignins than EG. Lower lignin-binding was detected when using the enzyme without CBM and the linker domain, thus, CBM was found to play an important role in protein adsorption [2], which could explain the least inhibition of BG by lignin.

\section{Lignin properties and possible mechanism for adsorption differences}

To understand the reasons for the differences in their adsorption capacities of protein, the properties of the lignins were investigated using Fourier transform infrared spectroscopy (FTIR), nuclear magnetic resonance (NMR) spectra, and gel permeation chromatography (GPC) methods.

\section{FTIR analysis of lignins}

Signal assignment and relative intensities in the FTIR spectra of lignins are shown in Table 1. Compared with $\mathrm{KL}$ and $\mathrm{AL}, \mathrm{CL}$ had much lower intensities at 2,938, $2,879,2,845 \mathrm{~cm}^{-1}$ (C-H vibrations in the methyl and methylene groups), and $1,462 \mathrm{~cm}^{-1}$ (C-H deformations in the methyl groups and aromatic ring vibrations), suggesting a higher $\mathrm{H}$ unit content and lower $\mathrm{S}$ unit content, because $\mathrm{H}$ units had no $\mathrm{OCH}_{3}$ groups, and $\mathrm{S}$ units had two $\mathrm{OCH}_{3}$ groups linked to aromatic rings, confirming that $\mathrm{CL}$ could be referred to as a GSH lignin. Moreover, in $\mathrm{CL}$, the significantly higher intensity at $830 \mathrm{~cm}^{-1}$ and the additional band at $1,168 \mathrm{~cm}^{-1}$ (typical for $\mathrm{GSH}$ lignin, except when indicating an antisymmetric C-O stretching of ester groups) also confirms this point [10]. The low intensity at $1,123 \mathrm{~cm}^{-1}$ (aromatic C-H deformation in $\mathrm{S}$ ring) and high intensity at $1,032 \mathrm{~cm}^{-1}$ (aromatic $\mathrm{C}-\mathrm{H}$ in plane deformation $\mathrm{G}+\mathrm{S}$ ) suggests a lower S/G ratio in CL than KL and AL. KL had higher intensities at 2,938,2,879,2,845, 1,462, and $1,123 \mathrm{~cm}^{-1}$, and lower adsorption at $1,268 \mathrm{~cm}^{-1}$ than $\mathrm{AL}$, suggesting higher $\mathrm{S}$ unit content, lower $\mathrm{G}$ unit content, and higher $\mathrm{S} / \mathrm{G}$ ratio. $\mathrm{AL}$ (hardwood) is known to be GS-type, which the intensity at 1,168 (none) and $833 \mathrm{~cm}^{-1}(0.15)$ also confirms. The zero adsorption at $1,168 \mathrm{~cm}^{-1}$ and the little intensity at $833 \mathrm{~cm}^{-1}(0.20)$ means that KL had very low $\mathrm{H}$ unit content, which indicates that $\mathrm{KL}$ is between hardwoods (GS) and grasses (GSH) in terms of lignin. The lower intensity at 2,879, 1,462, 1,123, and $830 \mathrm{~cm}^{-1}$ and the almost zero adsorption at $1,329 \mathrm{~cm}^{-1}$ reveals the G-type of PL.

Compared with KL and AL, CL had much higher intensities at $1,225,1,083$, and $1,168 \mathrm{~cm}^{-1}$ (ester group), indicating the lower amount of carboxylic acid groups, which has negative correlation with protein adsorption affinity by reducing the hydrophobic interactions $[6,11]$. In previous studies, the increase in the amount of phenolic hydroxyls 
Table 1 Signal assignment and relative intensities in FTIR spectra of lignins

\begin{tabular}{|c|c|c|c|c|c|c|c|}
\hline Assignment & Peak cm ${ }^{-1}$ & $\mathrm{KL}$ & $\mathrm{CL}$ & $\mathrm{AL}$ & $\mathrm{PL}$ & $\mathrm{ACL}$ & ASL \\
\hline $\mathrm{O}-\mathrm{H}$ stretching in aromatic and aliphatic hydroxyl groups & 3,446 & 2.00 & 1.69 & 1.62 & 1.54 & 5.56 & 5.25 \\
\hline \multirow[t]{3}{*}{$\mathrm{C}-\mathrm{H}$ vibrations in the methyl and methylene groups } & 2,938 & 0.56 & 0.42 & 0.49 & 0.55 & 0.70 & 0.64 \\
\hline & 2,879 & 0.36 & 0.30 & 0.33 & 0.26 & 0.34 & 0.30 \\
\hline & 2,845 & 0.31 & 0.22 & 0.29 & 0.30 & 0.40 & 0.36 \\
\hline Nonconjugated carbonyl groups ( $\mathrm{C}=\mathrm{O}$ stretch) & 1,724 & 0.58 & 1.12 & 0.69 & 0.46 & - & - \\
\hline \multirow[t]{3}{*}{ Aromatic skeleton vibration } & 1,594 & 1.17 & 1.25 & 1.05 & 0.73 & - & - \\
\hline & 1,507 & 1.00 & 1.00 & 1.00 & 1.00 & 1.00 & 1.00 \\
\hline & 1,422 & 0.79 & 0.66 & 0.73 & 0.40 & 0.55 & 0.43 \\
\hline $\mathrm{C}-\mathrm{H}$ deformations and aromatic ring vibrations (methyl) & 1,462 & 1.01 & 0.89 & 0.95 & 0.61 & 0.54 & 0.47 \\
\hline Phenolic hydroxyl groups & 1,384 & 0.47 & 0.61 & 0.46 & 0.14 & - & - \\
\hline Syringyl ring breathing, $\mathrm{C}-\mathrm{O}$ stretch & 1,329 & 0.45 & 0.54 & 0.51 & 0.01 & 0.09 & 0.02 \\
\hline Guaiacyl C-O units & 1,268 & 0.52 & - & 0.82 & 0.64 & 0.74 & 0.89 \\
\hline \multirow[t]{2}{*}{ Aromatic methyl ether bridges } & 1,225 & 0.86 & 1.13 & 0.83 & 0.38 & 1.00 & 0.90 \\
\hline & 1,083 & - & 1.08 & - & 0.25 & 1.08 & 1.05 \\
\hline C-O stretch in ester group & 1,168 & - & 1.01 & - & - & 0.80 & - \\
\hline Aromatic $\mathrm{C}-\mathrm{H}$ deformation in syringyl ring & 1,123 & 1.85 & 1.38 & 1.37 & 0.47 & 1.54 & 1.26 \\
\hline Aromatic $\mathrm{C}-\mathrm{H}$ in plane deformation $\mathrm{G}+\mathrm{S}$ & 1,032 & 1.10 & 1.46 & 0.98 & 0.64 & 1.21 & 1.33 \\
\hline Aromatic $\mathrm{C}-\mathrm{H}$ out of plane $\mathrm{C}-\mathrm{H}$ out of plane in position 2 and 6 of $\mathrm{S}$, and in all positions of $\mathrm{H}$ & 830 & 0.20 & 0.37 & 0.15 & 0.07 & 0.21 & 0.15 \\
\hline
\end{tabular}

in lignin has been linked to increased enzyme binding/inhibition capacity [12]. A study using lignin model compounds confirms that phenolic hydroxyl groups, which are important and necessary sites for the protein-adsorption and protein-precipitation capacity of tannins and lignins, play a key role in lignin-enzyme interactions [9]. Ximenes et al. [13] have also reported an increase in the inhibition and/or deactivation effect caused by the addition of soluble phenolic compounds, which could inactivate enzymes by reversibly or irreversibly complexing them. Rahikainen et al. [2] found that the higher content of phenolic hydroxyls in steam explosion pretreated lignins compared to the untreated lignins is a possible explanation of the higher affinity of the studied cellulases on steam explosion pretreated lignins. In this study, CL was found to have a significantly higher phenolic hydroxyl $\left(1,384 \mathrm{~cm}^{-1}\right)$ content compared to KL and AL (Table 1), which is a possible factor that contributes to higher adsorption capacity. However, these did not fit well for PL, which had the lowest intensities at $1,225,1,083,1,168$, and $1,384 \mathrm{~cm}^{-1}$, showing that there were other factors that caused the highest adsorption affinity on the enzyme.

Compared to ACL (wild-type), ASL had much lower intensities at 1,329 and $1,125 \mathrm{~cm}^{-1}$, and higher intensity at $1,268 \mathrm{~cm}^{-1}$, indicating a lower $\mathrm{S} / \mathrm{G}$ ratio. ASL was derived from Arabidopsis mutant 063792, in which the encoding gene of ferulate-5-hydroxylase (F5H), fah1, was SALK mutated to avoid S-type lignin formation. $\mathrm{F} 5 \mathrm{H}$ is a potential regulatory step in the determination of lignin monomer composition, which catalyzes an irreversible hydroxylation step in the pathway that diverts ferulic acid away from $G$ lignin biosynthesis and toward sinapic acid and S lignin [14]. Thus, ASL had no S lignin and reduced $S / G$ ratio because the total lignin content was the same in the two Arabidopsis lines. The S/G ratio was 0.12 and 0.02 (almost zero) for ACL and ASL, respectively, estimated using $\mathrm{Abs}_{1329} / \mathrm{Abs}_{1268}$ [15]. The low S/G ratio, which is one of the few differences between ACL and ASL, could be recognized as the main factor of the significant difference in the enzyme adsorption. And this result also shows that $G$ lignin has higher adsorption affinity than $S$ units. This may also be a reason why PL and CL showed higher affinity onto the protein compared to KL and AL.

\section{NMR analysis}

To further investigate the structural features of the lignins, the ${ }^{1} \mathrm{H}$ and ${ }^{13} \mathrm{C}$-NMR spectra of the milled wood lignins (MWL) from the different lignocellulosic materials were recorded (Figure 3). Assignment of signals in the ${ }^{1} \mathrm{H}$ and ${ }^{13} \mathrm{C}$-NMR spectra of lignin are shown in Table 2 and Table 3, respectively. In ${ }^{1} \mathrm{H}-\mathrm{NMR}$ spectra 


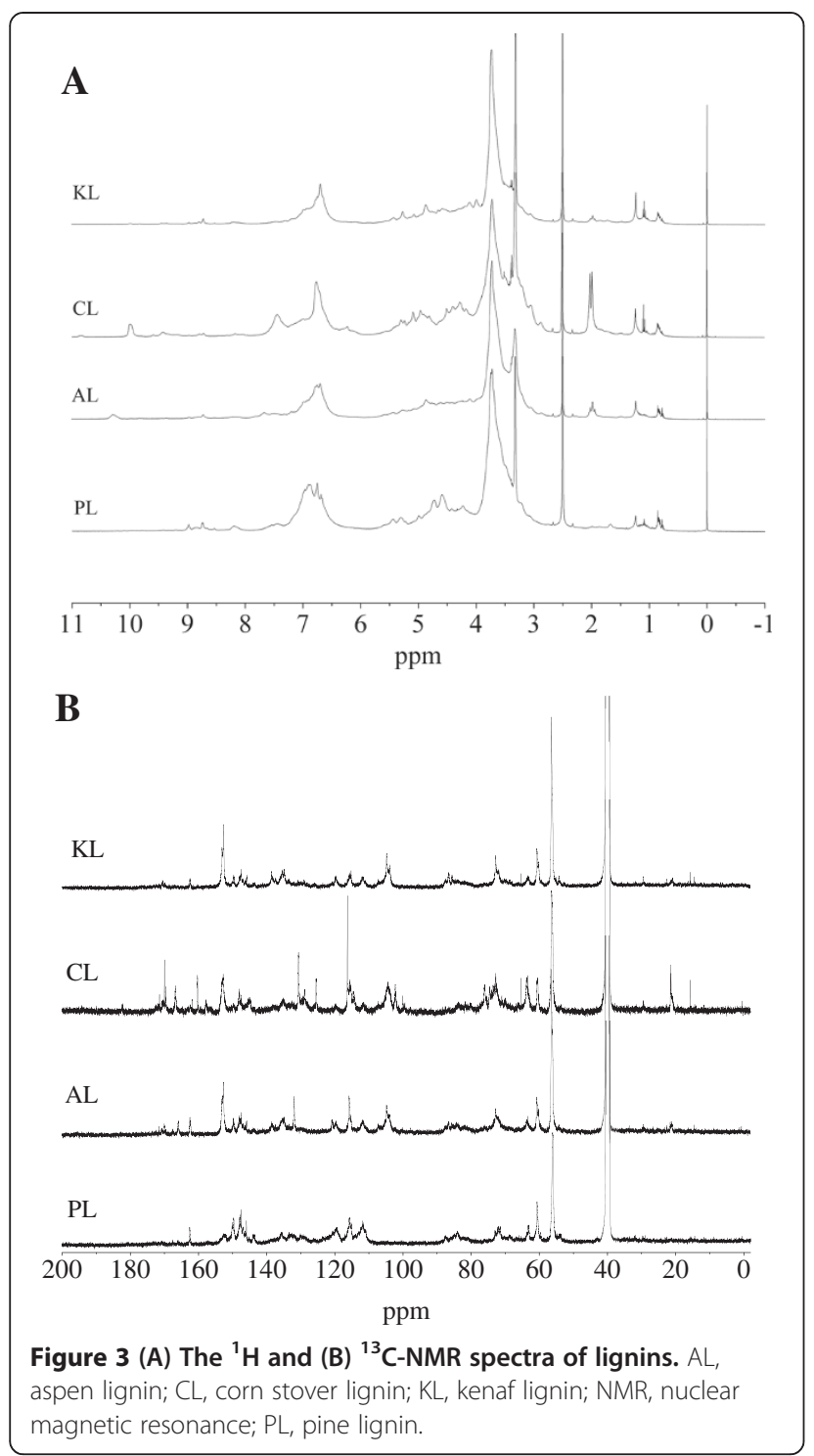

(Figure 3A), the CL had significantly strong adsorption at 7.4 (G lignin), which is in accordance with the FTIR analysis that CL had a high content of G lignin. PL had no adsorption and CL had higher adsorption at aliphatic $\mathrm{OH}(2.0$ and $1.9 \mathrm{ppm})$. A lower content of aliphatic hydroxyls in lignin reportedly affects higher enzyme binding/ inhibition capacity by increasing the surface hydrophobicity [1], which probably explains the higher adsorption capacity of PL than that of CL.

The ${ }^{13} \mathrm{C}$-NMR spectra included the region of aromatic carbons between 103 and 162 ppm (155 to 142 aromatic $\mathrm{C}-\mathrm{O}, 142$ to 124 aromatic $\mathrm{C}-\mathrm{C}$, and 124 to 102 aromatic $\mathrm{C}-\mathrm{H}$ ) and the aliphatic carbon region (90 to $60 \mathrm{ppm}$ ) [16]. In the ${ }^{13} \mathrm{C}$-NMR spectra result (Figure 3B), the significantly strong adsorptions at 172.6, $170.9(\mathrm{C}=\mathrm{O})$,
Table 2 Assignment of signals in ${ }^{1} \mathrm{H}-\mathrm{NMR}$ spectra of lignin

\begin{tabular}{ll}
\hline ppm & Assignments \\
\hline 10.4 & $\mathrm{H}$ in $-\mathrm{OH}$ \\
7.4 & $\mathrm{H}$ in G \\
6.9 & $\mathrm{Ha}(\mathrm{a}, \beta$ in conjugated double bonds) \\
4.8 & $\mathrm{H \gamma}(\beta-5, \beta-1, \beta-\beta, \beta-\mathrm{O}-4)$ \\
4.0 & $\mathrm{H}_{\beta}(\beta-\mathrm{O}-4)$ \\
3.8 & $\mathrm{HOMe}$ (aromatic) \\
3.6 & \\
3.3 & $\mathrm{H}_{2} \mathrm{O}$ \\
2.6 & $\mathrm{DMSO}$ \\
2.0 & $\mathrm{H}$ in aliphatic $-\mathrm{OH}$ \\
1.9 & \\
1.2 & $\mathrm{H}$ in aliphatic $-\mathrm{OH}$ of high-shielding effect \\
1.1 & \\
0.8 & \\
0.0 & Unknown
\end{tabular}

DMSO, dimethyl sulfoxide; $G$, guaiacyl; $H$, hydroxyphenyl; NMR, nuclear magnetic resonance.

Table 3 Assignment of signals in ${ }^{13}$ C-NMR spectra of lignin

\begin{tabular}{|c|c|}
\hline ppm & Assignments \\
\hline 172.6 & $C=O$ \\
\hline \multicolumn{2}{|l|}{170.9} \\
\hline 166.3 & -COO- in FA and CA esters \\
\hline 161.6 & $\mathrm{C}-4$ in FA and CA esters \\
\hline 159.9 & $\mathrm{C}-4$ in $\mathrm{H}$ \\
\hline 152.1 & $C-3 / C-5$ in $S$ etherified, $C-3 / C^{\prime}-3$ in $5-5^{\prime}$ etherified \\
\hline 147.2 & $C-3 / C-5$ in $S, C-4 / C-3$ in $G$ \\
\hline 145.2 & C- $a$ in FA and CA esters, C-4 in G not etherified \\
\hline 130.0 & $\mathrm{C}-2 / \mathrm{C}-6$ in FA and CA ethers \\
\hline 124.7 & C-a in coniferyl alcohol \\
\hline 115.8 & $\mathrm{C}-3 / \mathrm{C}-5$ in $\mathrm{FA}$ and $\mathrm{CA}$ esters, $\mathrm{C}-3 / \mathrm{C}-5$ in $\mathrm{H}, \mathrm{C}-5$ in $\mathrm{G}$ \\
\hline 113.7 & $C-2$ in $G$ \\
\hline 103.6 & $C-2 / C-6$ in $S$ \\
\hline 83.0 & $C_{-\beta}$ in $\beta-O-4, C-\alpha$ in $\beta-5$ and $\beta-\beta$ \\
\hline 72.3 & $\mathrm{C}-\mathrm{a}$ in $\beta-\mathrm{O}-4$ \\
\hline 66.2 & $C-\gamma$ in $\beta-5$ \\
\hline 62.8 & C-5 in xyl internal unit \\
\hline 60.1 & $\mathrm{C}-\gamma$ in $\beta-\mathrm{O}-4$ \\
\hline 55.7 & $-\mathrm{OCH}_{3}$ \\
\hline 28.9 & $-\mathrm{CH} 2-(\mathrm{C} 5-\mathrm{CH} 2-\mathrm{C} 5)$ \\
\hline 21.0 & $-\mathrm{CH} 3$ in acetyl group \\
\hline 15.2 & $\gamma$-methyl in $n$-propyl side chain \\
\hline
\end{tabular}

CA, $p$-coumaric acid; FA, ferulic acid; G, guaiacyl; $H$, hydroxyphenyl; NMR, nuclear magnetic resonance; $S$, syringyl. 
166.3 (-COO-), 159.9, 128 (H units), 147.2 (G+S), and $145.2 \mathrm{ppm}(\mathrm{G})$ in CL were in accordance with the FTIR analysis. Esterified $p$-coumaric acid, as a precursor of $\mathrm{H}$ units and a usual content in monocotyledonous plants, was clearly indicated by strong signals at 167, 161, 130.5, 125.5, and 116 ppm, further supporting the GSH-type for CL [16]. The significant adsorption at $21.0 \mathrm{ppm}\left(\mathrm{CH}_{3}\right.$ - in acetyl groups) in $\mathrm{CL}$ also supports the significant adsorption at $15.2 \mathrm{ppm}$ ( $\gamma$-methyl in $n$-propyl side chain), like the analysis of FTIR and ${ }^{13} \mathrm{C}-\mathrm{NMR}$ (more $\mathrm{C}=\mathrm{O}$ ). No adsorption at 152.1 and $103.6 \mathrm{ppm}$ (S units) and the higher intensity at 147.2 and 145.2 (G units), further supports the G-type for PL.

Two-dimensional heteronuclear single quantum coherence (2D-HSQC) NMR has been capable of providing important structural information on lignin, for example, substructures (inter-coupling bonds). The HSQC spectra showed three regions corresponding to aliphatic $\left(\delta_{\mathrm{C}} / \delta_{\mathrm{H}}\right.$ 10 to $50 / 0.5$ to 2.5$)$, lignin side chain $\left(\delta_{\mathrm{C}} / \delta_{\mathrm{H}} 50\right.$ to $90 / 2.5$ to 5.5$)$, and aromatic $\left(\delta_{\mathrm{C}} / \delta_{\mathrm{H}} 100\right.$ to $150 / 5.5$ to 8.5$)$ regions [10]. The assignments of ${ }^{13} \mathrm{C}-{ }^{1} \mathrm{H}$ cross-signals in the HSQC spectra are shown in Table 4. The aliphatic (nonoxygenated) region showed no signals with structural information (except for the presence of acetate signals at $\left.\delta_{\mathrm{C}} / \delta_{\mathrm{H}} 20.7 / 1.74\right)$, and therefore is not discussed in detail. In the side-chain region, methoxyls $\left(\mathrm{OCH}_{3}, \delta_{\mathrm{C}} /\right.$ $\left.\delta_{\mathrm{H}} 56.2 / 3.73\right)$ and side-chains in $\beta-\mathrm{O}-4$ substructures were the most prominent in all of the lignins (Figure $4 \mathrm{~A}$ ). Compared to other lignins, $\mathrm{CL}$ was weak in $\mathrm{A}_{\beta}\left(\mathrm{C}_{\beta}-\mathrm{H}_{\beta}\right.$ in $\left.\gamma-\mathrm{OH} \beta-\mathrm{O}-4, \delta_{\mathrm{C}} / \delta_{\mathrm{H}} 86.5 / 4.10\right), \mathrm{A}_{\beta}^{\prime}\left(\mathrm{C}_{\beta}-\mathrm{H}_{\beta}\right.$ in $\gamma-$ acylated $\left.\beta-\mathrm{O}-4, \delta_{\mathrm{C}} / \delta_{\mathrm{H}} 83.6 / 4.32\right)$, and $\mathrm{C}_{\gamma}\left(\mathrm{C}_{\gamma}-\mathrm{H}_{\gamma}\right.$ in $\beta-\beta$, $\delta_{\mathrm{C}} / \delta_{\mathrm{H}} 71.7 / 3.81$ and 4.17$)$, and there was no adsorption in $\mathrm{C}_{\beta}\left(\mathrm{C}_{\beta}-\mathrm{H}_{\beta}\right.$ in $\left.\beta-\beta, \delta_{\mathrm{C}} / \delta_{\mathrm{H}} 53.7 / 3.12\right)$ and $\mathrm{B}_{\beta}\left(\mathrm{C}_{\alpha}-\mathrm{H}_{\alpha}\right.$ in $\left.\beta-5, \delta_{C} / \delta_{H} 87.7 / 5.45\right)$. PL had no signal for $D_{\alpha}\left(C_{\alpha}-H_{\alpha}\right.$ in $\left.\beta-1, \delta_{C} / \delta_{H} 82.1 / 5.12\right)$ and $D_{\alpha^{\prime}}\left(C_{\alpha^{\prime}}-H_{\alpha^{\prime}}\right.$ in $\beta-1, \delta_{C} / \delta_{H}$ $85.4 / 4.80)$. In the aromatic regions of lignins, cross-signals from $\mathrm{H}, \mathrm{S}$, and $\mathrm{G}$ lignin units were observed (Figure $4 \mathrm{~B}$ ). The S-lignin units show a prominent signal for the $C_{2,6^{-}}$ $\mathrm{H}_{2,6}$ correlation at $\delta_{\mathrm{C}} / \delta_{\mathrm{H}} 103.8 / 6.68$, whereas the $\mathrm{G}$ units show different correlations for $\mathrm{C}_{2}-\mathrm{H}_{2}, \mathrm{C}_{5}-\mathrm{H}_{5}$, and $\mathrm{C}_{6}-\mathrm{H}_{6}$ at $\delta_{\mathrm{C}} / \delta_{\mathrm{H}} 111.5 / 6.99,115.2 / 6.71$ and 6.94 , and $119.5 / 6.83$, respectively. The $\mathrm{C}_{2,6}-\mathrm{H}_{2,6}$ aromatic correlations from $\mathrm{H}$ units $\left(\delta_{\mathrm{C}} / \delta_{\mathrm{H}} 128.2 / 7.17\right)$ were significantly observed in $\mathrm{CL}$,

Table 4 Assignment of ${ }^{13} \mathrm{C}-{ }^{1} \mathrm{H}$ cross-signals in the HSQC spectra of lignin

\begin{tabular}{|c|c|c|}
\hline Labels & $\delta_{\mathrm{C}} / \delta_{\mathrm{H}}(\mathrm{ppm})$ & Assignments \\
\hline$C_{\beta}$ & $53.7 / 3.12$ & $\mathrm{C}_{\beta}-\mathrm{H}_{\beta}$ in $\beta-\beta$ (resinol) substructures (C) \\
\hline$D_{\beta}$ & $56.1 / 3.09$ & $\mathrm{C}_{\beta}-\mathrm{H}_{\beta}$ in $\beta-1$ (spirodienone) substructures (D) \\
\hline$-\mathrm{OCH}_{3}$ & $57.3 / 3.77$ & $\mathrm{C}-\mathrm{H}$ in methoxyls \\
\hline AY & $60.0 / 3.38$ to 3.71 & $\mathrm{C}_{\gamma}-\mathrm{H} \gamma$ in $\beta-\mathrm{O}-4$ substructures (A) \\
\hline$A^{\prime} Y$ & $63.8 / 3.83$ to 4.30 & $C_{\gamma}-\mathrm{H} \gamma$ in $\gamma$-acylated $\beta-O-4^{\prime}$ substructures $\left(A^{\prime}\right.$ and $\left.A^{\prime \prime}\right)$ \\
\hline$C_{\gamma}$ & 71.7/3.81 and 4.17 & $\mathrm{C}_{\gamma}-\mathrm{H} \gamma$ in $\beta-\beta$ (resinol) substructures (C) \\
\hline$A a / A^{\prime} a$ & $72.3 / 4.86$ & $\mathrm{Ca}-\mathrm{Ha}$ in $\beta-\mathrm{O}-4$ substructures $\left(A, A^{\prime}\right.$, and $A^{\prime \prime}$ ) \\
\hline $\mathrm{Da}$ & $82.1 / 5.12$ & Ca-Ha in $\beta-1$ (spirodienone) substructures (D) \\
\hline$A_{\beta}^{\prime}$ & $83.6 / 4.32$ & $\mathrm{C}_{\beta}-\mathrm{H}_{\beta}$ in $\gamma$-acylated $\beta-\mathrm{O}-4$ substructures $\left(\mathrm{A}^{\prime}\right.$ and $\left.\mathrm{A}^{\prime \prime}\right)$ \\
\hline $\mathrm{Ca}$ & $85.4 / 4.64$ & $\mathrm{Ca}-\mathrm{Ha}$ in $\beta-\beta$ (resinol) substructures (C) \\
\hline $\mathrm{Da}$ & $85.4 / 4.80$ & $\mathrm{Ca}-\mathrm{Ha}$, in $\beta-1$ (spirodienone) substructures (D) \\
\hline$A_{\beta}$ & $86.5 / 4.10$ & $\mathrm{C}_{\beta}-\mathrm{H}_{\beta}$ in $\gamma-\mathrm{OH} \beta-\mathrm{O}-4$ substructures (A) \\
\hline $\mathrm{Ba}$ & $87.7 / 5.45$ & Ca-Ha in $\beta-5$ (phenylcoumaran) substructures (B) \\
\hline $\mathrm{S}_{2,6}$ & $103.8 / 6.68$ & $\mathrm{C}_{2}-\mathrm{H}_{2}$ and $\mathrm{C}_{6}-\mathrm{H}_{6}$ in etherified syringyl units \\
\hline $\mathrm{S}_{2,6}(\mathrm{Ca}=\mathrm{O})$ & 106.7/7.36 and 7.21 & $\mathrm{C}_{2}-\mathrm{H}_{2}$ and $\mathrm{C}_{6}-\mathrm{H}_{6}$ in oxidized $(\mathrm{Ca}=\mathrm{O})$ syringyl units \\
\hline $\mathrm{G}_{2}$ & $111.5 / 6.99$ & $\mathrm{C}_{2}-\mathrm{H}_{2}$ in guaiacyl units \\
\hline $\mathrm{D}_{2^{\prime}}$ & $111.6 / 6.23$ & $C_{2^{\prime}}-H_{2}$ in $\beta-1$ (spirodienone) substructures (D) \\
\hline$A_{\beta^{\prime}}^{\prime \prime}$ & $114.3 / 6.24$ & $\mathrm{C}_{\beta^{\prime}} \mathrm{H}_{\beta^{\prime}}$ in $p$-coumaroylated substructures $\left(\mathrm{A}^{\prime \prime}\right)$ \\
\hline $\mathrm{G}_{5}$ & $115.2 / 6.71$ and 6.94 & $\mathrm{C}_{5}-\mathrm{H}_{5}$ in guaiacyl units \\
\hline$A^{\prime \prime} 3^{\prime} 5^{\prime}$ & $116.2 / 6.77$ & $\mathrm{C}_{3^{\prime}}-\mathrm{H}_{3^{\prime}}$ and $\mathrm{C}_{5^{\prime}}-\mathrm{H}_{5^{\prime}}$ in p-coumaroylated substructures $\left(\mathrm{A}^{\prime \prime}\right)$ \\
\hline$D_{6^{\prime}}$ & $118.3 / 6.19$ & $\mathrm{C}_{6^{\prime}}-\mathrm{H}_{6^{\prime}}$ in $\beta-1$ (spirodienone) substructures (D) \\
\hline $\mathrm{G}_{6}$ & $119.5 / 6.83$ & $\mathrm{C}_{6}-\mathrm{H}_{6}$ in guaiacyl units \\
\hline $\mathrm{H}_{2,6}$ & $128.2 / 7.17$ & $\mathrm{C}_{2}-\mathrm{H}_{2}$ and $\mathrm{C}_{6}-\mathrm{H}_{6}$ in $p$-hydroxyphenyl units \\
\hline$A^{\prime \prime}{ }_{2^{\prime}, 6^{\prime}}$ & $130.5 / 7.4$ & $\mathrm{C}_{2^{\prime}}-\mathrm{H}_{2^{\prime}}$ and $\mathrm{C}_{6^{\prime}}-\mathrm{H}_{6^{\prime}}$ in p-coumaroylated substructures $\left(\mathrm{A}^{\prime \prime}\right)$ \\
\hline$A^{\prime \prime} a^{\prime}$ & $145.1 / 7.39$ & Ca-Ha, in p-coumaroylated substructures $\left(A^{\prime \prime}\right)$ \\
\hline
\end{tabular}




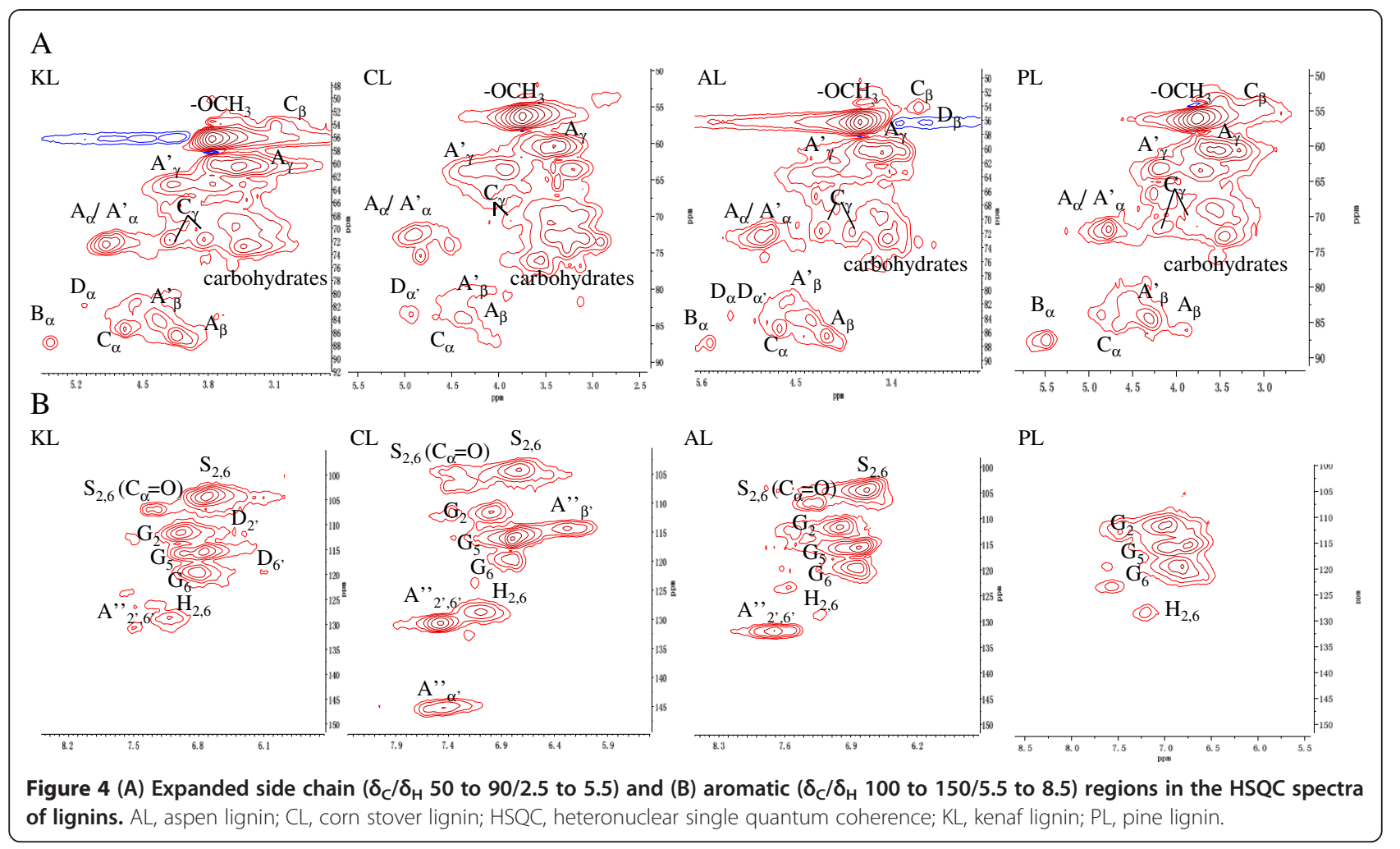

had weak signals in $\mathrm{KL}$, and had trace content in $\mathrm{AL}$ and PL, in accordance with the FTIR analysis. The $\mathrm{A}^{\prime \prime}{ }_{\alpha^{\prime}}\left(\mathrm{C}_{\alpha^{\prime-}}\right.$ $\mathrm{H}_{\alpha}$, in $p$-coumaroylated substructures $)$ and $\mathrm{A}^{\prime \prime}{ }_{\beta^{\prime}}\left(\mathrm{C}_{\beta^{\prime}}, \mathrm{H}_{\beta}\right.$, in $p$-coumaroylated substructures) are clearly observed only in $\mathrm{CL}$, in accordance with the FTIR and ${ }^{13} \mathrm{C}-\mathrm{NMR}$ analysis, also further supporting the GSH-type of CL. No adsorption was observed at any signal for $S$ units and main adsorption at any signal for $G$ units, which also further supported the G-type for PL, also in accordance with the FTIR analysis.

\section{Lignin composition}

Based on the number of carbons per aromatic ring of the C-2 of $\mathrm{G}$ units, C-2/C-6 of S units, and C-4 of $\mathrm{H}$ units in ${ }^{13} \mathrm{C}-\mathrm{NMR}[16]$, the $\mathrm{S} / \mathrm{G}$ ratios were established to be $2.89,0.87,1.67$, and 0 for $\mathrm{KL}, \mathrm{CL}, \mathrm{AL}$, and PL, respectively. S/G/H ratio was 0.62:0.71:1 for $\mathrm{CL}$, in accordance with the FTIR and NMR analysis that shows that $H$ lignin was abundant. Even though kenaf is a herbaceous plant, the analysis shows that KL tended to have the hardwood lignin (GS-type), which was demonstrated by the high $\mathrm{S} / \mathrm{G}$ ratio, the absence of signal for $p$-coumaric acid in ${ }^{13} \mathrm{C}-\mathrm{NMR}$ and 2D-HSQC NMR, and the low content of $\mathrm{H}$ units in FTIR and NMR analyses. Previous analysis from FTIR showed that the low S/G ratio was the main factor of the significant difference in the adsorption of enzyme onto ACL and ASL, and G lignin had higher adsorption capacity on protein than $\mathrm{S}$ units. Moreover, according to the results of adsorption and the analysis of $\mathrm{S} / \mathrm{G}$ ratio in lignins, $\mathrm{S} / \mathrm{G}$ ratio had a good negative correlation between $S / G$ ratio and adsorbed protein content $\left(R^{2}=0.94\right)$, which means that low $\mathrm{S} / \mathrm{G}$ ratio could be confirmed as one factor of the high adsorption capacity for lignin. Figure 4 shows that the amount of $\mathrm{H}$ units decreased in the order $\mathrm{CL}>\mathrm{KL}>\mathrm{PL}>$ AL. The almost equivalent amount of $\mathrm{H}$ units in $\mathrm{PL}$ and $\mathrm{AL}$, and the greater adsorption capacity of PL than AL indicate that the concentration of the $\mathrm{H}$ unit in lignin did not affect the adsorption capacity. CL had more $\mathrm{H}$ units and weaker affinity than PL, and KL had more $\mathrm{H}$ units and weaker adsorption capacity than AL and PL, indicating that the increase in the amount of $\mathrm{H}$ units did not increase the adsorption capacity. $\mathrm{CL}$ had more $\mathrm{H}$ units and greater affinity than $\mathrm{KL}$, demonstrating that the increase in the amount of $\mathrm{H}$ units did not decrease the affinity. These results show that the amount of $\mathrm{H}$ units may not be related to the adsorption capacity.

Even though the influence of altering the S/G ratio of the moieties in lignin on the chemical and physical properties of the cell wall and glucose yield is being actively studied $[4,5,17]$, there are no studies about the effect of the amount of the $\mathrm{H}$ unit on the enzymatic digestibility of the biomass and the three lignin monomers on adsorption capacity until now. In the enzymatic 
hydrolysis, Arabidopsis mutant 063792 not only presented higher cellulose conversion compared to Arabidopsis wild-type Col-0, whether with high or low enzyme dosage (data not shown), but also increased cellulose conversion much higher with low enzyme dosage (48\%) than with high enzyme dosage (14\%), although there is almost same content of total lignin in the two Arabidopsis lines. This result further demonstrates that the low S/G ratio produced high glucose yield for untreated samples [5], and $\mathrm{S}$ units rendered more resistance to degradation by cellulase [18], which more significantly appeared with low enzyme dosage and sufficiently counteracted the lower adsorption on cellulase. Papa et al. [5] reported that high lignin-S/G ratio produced low glucose yields for untreated samples $(r=-0.97 ; P<0.03 ; \mathrm{n}=4)$, but the alteration of lignin-S/G ratio did not affect the glucose yield after ionic liquid (IL) pretreatment, which is attributed to the high efficacy of IL pretreatment that masked the effect of the altered $\mathrm{S} / \mathrm{G}$ ratios. The $\mathrm{S} / \mathrm{G}$ ratio has also been reported to affect enzymatic hydrolysis because it affects lignin crosslinking, and thus, the three-dimensional structure of the plant cell wall and enzyme accessibility [17]. The chemical composition and the structural elements of lignin are regarded as barriers to enzymatic hydrolysis [19]. The downregulation of $\mathrm{S}$ units also leads to the incorporation of novel units into the lignin that arises from the intermediates in the lignin synthesis pathway [20], such as 5hydroxyconiferyl alcohol. The inclusion of these novel intermediates may 'loosen' the overall lignin structure and are responsible for improving its digestibility. Pan [9] also stated that the concentration of lignin methoxyl groups is highly negatively correlated with the degradation of the cell wall, and believed that the high likelihood of quinone methide formation is the reason for the greater inhibitory effect of $\mathrm{S}$ units than $\mathrm{G}$ units.

\section{Molecular weight determination}

The weight average molecular weights $(\mathrm{Mw})$, number average molecular weights $(\mathrm{Mn})$, and PDI (Mw/Mn) of the lignins were determined using GPC analysis (Table 5). The average molecular weight of the lignins from the different types of lignocellulosics and PDI were difficult to relate to protein binding, which was also reported in other studies [6]. Nevertheless, GPC showed that PL and CL

\section{Table 5 Molecular weights and polydispersity index} of lignins

\begin{tabular}{lccc}
\hline Lignin sample & Mn (Da) & Mw (Da) & Polydispersity (Mw/Mn) \\
\hline $\mathrm{KL}$ & 36,719 & 147,755 & 4.02 \\
$\mathrm{CL}$ & 44,530 & 163,802 & 3.68 \\
$\mathrm{AL}$ & 47,389 & 224,615 & 4.74 \\
$\mathrm{PL}$ & 20,039 & 78,149 & 3.90 \\
\hline
\end{tabular}

$\mathrm{AL}$, aspen lignin; $\mathrm{CL}$, corn stover lignin; $\mathrm{KL}$, kenaf lignin; $\mathrm{Mn}$, number average molecular weights; $\mathrm{Mw}$, weight average molecular weights; $\mathrm{PL}$, pine lignin. had more uniform lignin fragment size than AL and KL, which is favorable for the interaction with proteins by higher plasticity [1]. The uniformity in lignin fragment size decreased in the order PL, CL $>\mathrm{AL}>\mathrm{KL}$, which is in accordance with the order of adsorption capacity.

\section{Conclusions}

Through the comparison of the protein adsorptions onto six lignins and the examination of the properties of the lignins, lignin sources were found to affect enzyme adsorption through their lignin composition and structural features, like functional groups, such as carboxylic acid, aliphatic hydroxyl, and phenolic hydroxyl groups. The adsorption capacity decreased in the order $\mathrm{PL}>\mathrm{CL}>\mathrm{AL}>$ KL. The lower the S/G ratio, the higher affinity was observed. For mono-component enzymes, the adsorption capacity decreased in the order $\mathrm{CBH}$, xylanase $>\mathrm{EG}>\mathrm{BG}$. The investigations in this paper not only reveal the differences of lignin properties among diverse biomass, the adsorption capacity of the enzymes to lignins, and its possible mechanism, but also provides the reference for the genetic modification of lignocellulosic biomass and enzymes.

\section{Methods}

\section{Microorganism and biomass materials}

P. oxalicum JUA10-T, a mutant from Pcp oxalicum JUA10, was stored in the laboratory. The medium composition for cellulase production was based on that previously described [21].

Kenaf stalk and corn stover were obtained from Xinjiang Uygur Autonomous Region and Shandong Province, China, respectively, and aspen and pine (Pinus massoniana Lamb.) were provided by Tianjin University of Science and Technology, Tianjin, China. Arabidopsis Col-0 (wild-type) and Arabidopsis mutant 063792 (SALK mutant of fah1) were generously granted by the Botany Laboratory at Shandong University, Shandong Province, China.

\section{Preparation of lignins, holocellulose, and PASC}

The MWL from kenaf, corn stover, aspen, pine ( $P$. massoniana Lamb.), Arabidopsis Col-0, and Arabidopsis SALK mutant 063792 in this study were isolated from lignocelluloses according to the description in the literature [22]. MWL is a lignin preparation considered to be the most representative of the whole native lignin in the plant [22], and is mainly used to study the structure of lignin $[10,16]$ despite its low yield. However, the isolated MWL is the only lignin fraction that was extracted using aqueous dioxane (96\%) solution, and did not represent the structure and characteristics of all the lignin in the plant. The holocellulose from Arabidopsis Col-0 and PASC $(1 \%, w / v)$ were prepared according to the description by Eom et al. [23] and Zhang et al. [24], respectively. 


\section{Enzyme adsorption}

The adsorption of the enzyme preparation to lignins was performed in polypropylene tubes $(2 \mathrm{~mL})$ using $3.3 \%(\mathrm{w} / \mathrm{v})$ lignin and $5.4 \mathrm{mg} \mathrm{g}^{-1}$ lignin of protein in $50 \mathrm{mM}$ sodium acetate buffer $(\mathrm{pH} 4.8)$ at $45^{\circ} \mathrm{C}$ for $48 \mathrm{~h}$ in a rotary shaker (QB-228, Kylin-Bell Lab Instruments Co., Ltd, Haimen, Jiangsu Province, China). Lignins appeared to be insoluble. Samples were centrifuged $(10,000 \mathrm{rpm}, 10 \mathrm{~min})$ and the liquid containing the unbound enzymes was collected (adsorption supernatant) for further analysis. Controls lacking lignin or enzyme were used as reference.

\section{Protein analysis and enzyme assays}

Protein concentrations were determined using the method described by Bradford [25]. The activities of CBH, EG, BG, and xylanase were assayed using $1 \% p \mathrm{NPC}, \mathrm{CMC}-\mathrm{Na}$, salicin, and xylose (Sigma-Aldrich, St Louis, MO, USA) as the substrate at $\mathrm{pH} 4.8\left(50 \mathrm{mM}\right.$ sodium acetate buffer) at $50^{\circ} \mathrm{C}$ for $30 \mathrm{~min}$ according to the procedures of Gao et al. [26] and Guo et al. [27]. One unit (U) of enzyme activity was defined as the amount of enzyme that liberated $1 \mu \mathrm{mol}$ of reducing sugar per minute under the assay conditions.

\section{Enzymatic hydrolysis}

The hydrolysis tests for Avicel (Sigma-Aldrich), holocellulose, and PASC were conducted using the enzyme and each lignin (3.3\%, $5.4 \mathrm{mg}$ protein $\mathrm{g}^{-1}$ lignin) at $45^{\circ} \mathrm{C}$ for $48 \mathrm{~h}$ in a rotary shaker (QB-228). The substrate for loading was double lignin. In the supernatant, glucose and xylose were determined using HPLC (Shimadzu, Kyoto, Japan) with a refractive index detector (Shimadzu) on an Aminex HPX87P column (Bio-Rad, Hercules, CA, USA) at a flow rate of $0.5 \mathrm{~mL} / \mathrm{min}$ at $78^{\circ} \mathrm{C}$, with water as the eluent. Samples lacking lignin or enzyme served as control.

\section{Lignin characterization}

The functional groups of the isolated lignins were analyzed using FTIR (Nexus, Thermo Nicolet, Thermo Fisher Scientific, Waltham, MA, USA), with KBr pellets, over the range of 400 to $4,000 \mathrm{~cm}^{-1}$, and NMR spectra with an Avance $400 \mathrm{MHz}$ spectrometer (Bruker, Billerica, MA, USA) at $25^{\circ} \mathrm{C}$ in DMSO-d6. For ${ }^{1} \mathrm{H}-\mathrm{NMR}, 10 \mathrm{mg}$ of lignin was dissolved in $0.5 \mathrm{~mL}$ DMSO- $\mathrm{d}_{6}$, and $100 \mathrm{mg}$ of lignin for ${ }^{13} \mathrm{C}-\mathrm{NMR}$ and $2 \mathrm{D}$-HSQC spectra. The sequence was conducted according to literature [10].

The molecular weights of the lignins were determined using GPC with dimethylformamide (DMF) [6].

\section{Abbreviations}

ACL: Arabidopsis Col-0 lignin; AL: Aspen lignin; ASL: Arabidopsis SALK mutant 063792 lignin; BG: $\beta$-glucosidase; CA: p-coumaric acid; CBH: Cellobiohydrolase; CBM: Carbohydrate-binding module; CL: Corn stover lignin; DMF: Dimethylformamide; DMSO: Dimethyl sulfoxide; DMSO-d6: Deuterated dimethyl sulfoxide; EG: Endoglucanase; F5H: Ferulate-5-hydroxylase; FA: Ferulic acid; FTR: Fourier transform infrared spectroscopy; G: Guaiacyl; GPC: Gel permeation chromatography; H: Hydroxyphenyl; HPLC: High performance liquid chromatography; HSQC: Heteronuclear single quantum coherence; IL: Ionic liquid; KL: Kenaf lignin; Mn: Number average molecular weights; Mw: Weight average molecular weights; MWL: Milled wood lignins; NMR: Nuclear magnetic resonance; PASC: Phosphoric acid-swollen cellulose; PDI: Polydispersity index; PL: Pine lignin; S: Syringyl.

\section{Competing interests}

The authors declare that they have no competing interests.

\section{Authors' contributions}

FFG performed the experiments, data analysis, and drafted the manuscript. WJS, WS, and FFW carried out the experiments, data analysis, and contributed to the manuscript draft. $X Z L, J Z$, and $Y B Q$ designed the project, critically analyzed the data, and revised the manuscript. All authors read and approved the final manuscript.

\section{Acknowledgements}

This study was financially supported by the National Key Basic Research Development Program (2011CB707401) and the National Natural Science Foundation of China $(21276143,21376141)$

Received: 18 January 2014 Accepted: 4 March 2014

Published: 14 March 2014

\section{References}

1. Berlin A, Balakshin M, Gilkes N, Kadla J, Maximenko V, Kubo S, Saddler J: Inhibition of cellulase, xylanase and beta-glucosidase activities by softwood lignin preparations. J Biotechnol 2006, 125:198-209.

2. Rahikainen JL, Martin-Sampedro R, Heikkinen H, Rovio S, Marjamaa K, Tamminen T, Rojas OJ, Kruus K: Inhibitory effect of lignin during cellulose bioconversion: the effect of lignin chemistry on non-productive enzyme adsorption. Bioresour Technol 2013, 133:270-278.

3. Yao L, Yue J, Zhao J, Dong JQ, Li XZ, Qu YB: Application of acidic wastewater from monosodium glutamate process in pretreatment and cellulase production for bioconversion of corn stover-feasibility evaluation. Bioresour Technol 2010, 101:8755-8761.

4. Dien BS, Miller DJ, Hector RE, Dixon RA, Chen F, McCaslin M, Reisend P, Sarathe G, Cotta MA: Enhancing alfalfa conversion efficiencies for sugar recovery and ethanol production by altering lignin composition. Bioresour Technol 2011, 102:6479-6486.

5. Papa G, Varanasi P, Sun L, Cheng G, Stavila V, Holmes B, Simmons BA, Adani $F$, Singh S: Exploring the effect of different plant lignin content and composition on ionic liquid pretreatment efficiency and enzymatic saccharification of Eucalyptus globulus L. mutants. Bioresour Technol 2012, 117:352-359.

6. Pareek N, Gillgren T, Jönsson LJ: Adsorption of proteins involved in hydrolysis of lignocellulose on lignins and hemicelluloses. Bioresour Technol 2013, 148:70-77.

7. Tu MB, Pan XJ, Saddler JN: Adsorption of cellulase on cellulolytic enzyme lignin from lodgepole pine. J Agric Food Chem 2009, 57:7771-7778.

8. Nakagame S, Chandra RP, Saddler JN: The effect of isolated lignins, obtained from a range of pretreated lignocellulosic substrates, on enzymatic hydrolysis. Biotechnol Bioeng 2010, 105:871-879.

9. Pan XJ: Role of functional groups in lignin inhibition of enzymatic hydrolysis of cellulose to glucose. J Biobased Mater Bioenerg 2008, 2:25-32.

10. Wen $J \mathrm{~L}$, Xue $B L, X u F$, Sun $R C$, Pinkert $A$ : Unmasking the structural features and property of lignin from bamboo. Ind Crop Prod 2013, 42:332-343.

11. Nakagame S, Chandra RP, Kadla JF, Saddler JN: Enhancing the enzymatic hydrolysis of lignocellulosic biomass by increasing the carboxylic acid content of the associated lignin. Biotechnol Bioeng 2011, 108:538-548.

12. Sewalt VJH, Glasser WG, Beauchemin KA: Lignin impact on fiber degradation. 3. Reversal of inhibition of enzymatic hydrolysis by chemical modification of lignin and by additives. J Agric Food Chem 1997, 45:1823-1828.

13. Ximenes E, Kim Y, Mosier N, Dien B, Ladisch M: Deactivation of cellulases by phenols. Enzyme Microb Technol 2011, 48:54-60.

14. Meyer K, Shirley AM, Cusumano JC, Bell-Lelong DA, Chapple C: Lignin monomer composition is determined by the expression of a cytochrome P450-dependent monooxygenase in Arabidopsis. Biochem 1998, 95:6619-6623. 
15. Gouveia S, Fernandez-Costas C, Sanroman MA, Moldes D: Enzymatic polymerisation and effect of fractionation of dissolved lignin from Eucalyptus globulus Kraft liquor. Bioresour Technol 2012, 121:131-138.

16. El Hage R, Brosse N, Chrusciel L, Sanchez C, Sannigrahi P, Ragauskas A: Characterization of milled wood lignin and ethanol organosolv lignin from miscanthus. Polym Degrad Stabil 2009, 94:1632-1638.

17. Grabber JH: How do lignin composition, structure, and cross-linking affect degradability? A review of cell wall model studies. Crop Sci 2005, 45:820-831.

18. Skyba O, Douglas CJ, Mansfield SD: Syringyl-rich lignin renders poplars more resistant to degradation by wood decay fungi. Appl Environ Microbiol 2013, 79:2560-2571.

19. Himmel ME, Ding SY, Johnson DK, Adney WS, Nimlos MR, Brady JW, Foust TD: Biomass recalcitrance: engineering plants and enzymes for biofuels production. Science 2007, 315:804-807.

20. Marita JM, Ralph J, Hatfield RD, Guo DJ, Chen F, Dixon RA: Structural and compositional modifications in lignin of transgenic alfalfa down-regulated in caffeic acid 3-0-methyltransferase and caffeoyl coenzyme A 3-0-methyltransferase. Phytochemistry 2003, 62:53-65.

21. Gao L, Wang FH, Gao F, Wang LS, Zhao J, Qu YB: Purification and characterization of a novel cellobiohydrolase (PdCel6A) from Penicillium decumbens JU-A10 for bioethanol production. Bioresour Technol 2011, 102:8339-8342.

22. Bjökman A: Studies on finely divided wood. Part 1. Extraction of lignin with neutral solvent. Svensk Papperstidning 1956, 59:477-485.

23. Eom IY, Kim KH, Kim JY, Lee SM, Yeo HM, Choi IG, Choi JW: Characterization of primary thermal degradation features of lignocellulosic biomass after removal of inorganic metals by diverse solvents. Bioresour Technol 2011, 102:3437-3444.

24. Zhang $Y H$, Cui J, Lynd LR, Kuang LR: A transition from cellulose swelling to cellulose dissolution by o-phosphoric acid: evidence from enzymatic hydrolysis and supramolecular structure. Biomacromolecules 2006, 7:644-648.

25. Bradford MM: A rapid and sensitive method for the quantitation of microgram quantities of protein utilizing the principle of protein-dye binding. Anal Biochem 1976, 72:248-254.

26. Gao L, Gao F, Wang LS, Geng CL, Chi LL, Zhao J, Qu YB: N-glycoform diversity of cellobiohydrolase I from Penicillium decumbens and synergism of nonhydrolytic glycoform in cellulose degradation. J Biol Chem 2012, 287:15906-15915.

27. Guo FF, Zou MY, Li XZ, Zhao J, Qu YB: An effective degumming enzyme from Bacillus sp. $Y 1$ and synergistic action of hydrogen peroxide and protease on enzymatic degumming of ramie fibers. Biomed Res Int 2013. doi: $10.1155 / 2013 / 212315$.

doi:10.1186/1754-6834-7-38

Cite this article as: Guo et al:: Differences in the adsorption of enzymes onto lignins from diverse types of lignocellulosic biomass and the underlying mechanism. Biotechnology for Biofuels 2014 7:38.

\section{Submit your next manuscript to BioMed Central and take full advantage of:}

- Convenient online submission

- Thorough peer review

- No space constraints or color figure charges

- Immediate publication on acceptance

- Inclusion in PubMed, CAS, Scopus and Google Scholar

- Research which is freely available for redistribution 